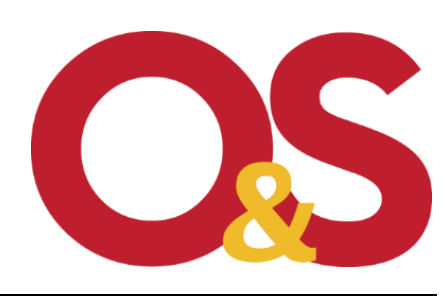

Journal Organizações \& Sociedade 2021

28(96), 156-177

(C) Authors 2021

DOI 10.1590/1984-92302021v28n9607EN

\title{
Corruption: Epistemological Reflections and Contributions to the Public Sector
}

Suélem Viana Macedo ${ }^{a}$

${ }^{a}$ Federal University of Viçosa, Viçosa, Brazil

\begin{abstract}
Corruption is a recurring phenomenon throughout history, so different conceptions seek to formulate a concept that defines it. This theoretical essay aims to introduce a perspective that broadens the understanding of corruption beyond the currents of thought that prevail in studies about Brazilian public administration. This study indicates that the epistemic reconstruction of the meaning of corruption should derive from the conception of public interest as a result of deliberative processes between citizens and the State. Such perspective contributes to the debate about the importance of participation of the civil society in controlling corruption and creating public interest itself. This study also highlights that more efficient control is not only restricted to legislation reforms but it also relies on the enhancement civic virtues.
\end{abstract}

Keywords: public administration; paradigms; public interest; social engagement.

\section{Introduction}

Corruption and its implications on public administration have been widely discussed in recent years. It is a recurring phenomenon in the history of many countries, which has survived institutional changes and that causes numerous negative effects on the State, the economy, the political regime and the legitimacy of governments (Cordis \& Milyo, 2016; Filgueiras, 2008; Klitgaard, 1994; Lambsdorff, 2003; Mauro, 1997). In Brazil, in particular, this theme is growing in contemporary political debate, mainly due to frequent episodes of lodged complaints involving members of the three powers of the State. The permanent incidence of corrupt practices in the political system of 
nations has fostered many conceptions that seek to explain their causes and formulate a concept that defines the corruption in precise terms (Avritzer \& Filgueiras, 2011; Heidenheimer \& Johnston,2002; Jain, 2001).

The history of political thought has understood corruption from different perspectives that were developed to explain the phenomenon. In general, the main theoretical perspectives that guide the analysis of corruption are: the legal positivist; the functionalist, which includes the patrimonialism approach; and the economic (Filgueiras, Montandon, Oliveira, \& Abreu, 2010; Pinho \& Sacramento, 2018); these last two models - functionalist and economic - have dominated Brazilian studies on corruption (Bignotto, 2011; Marani, Brito, Souza, \& Brito, 2018; Oliveira, Costa, \& Mendes, 2016). Thus, one of the greatest divergences among the authors who have already studied corruption arise from the lack of consensus regarding the exact conceptualization of what is a corrupt action (Biason, 2012; Brei, 1996; Gardiner, 2002; Nye, 1967; Souza, Midlej e Silva, \& Gomes, 2019).

No current approaches in Brazil develop the corruption theme in a way that integrates the political, economic, moral and cultural areas (Filgueiras, 2009). Most studies are comparative and try to measure the perception of corruption by the population to demonstrate its effects on the State and society (Avritzer, Bignotto, Guimarães, \& Starling, 2008; Marani et al., 2016). Moreover, researchers in the field of applied social sciences - especially within the scope of public administration - still debate about how knowledge is produced (Barbosa, Neves, Santos, Cassundé, \& Cassundé Jr., 2013). Although the field of Brazilian public administration has undergone several change, in which different paradigms have prevailed, a functionalistic conception of science and uncritical of the reality of the country prevails, where a dichotomy between politics and administration is still present (Andion, 2012; Paula, 2016; Santos, 2017).

Regarding the study of corruption, the legal positivist, functionalist and economic theoretical conceptions help to understand some relevant aspects of the phenomenon (Bignotto, 2011). However, they do not take into account cultural, social, moral and political elements, nor the concept of public interest as the very expression of society's political will (Filgueiras, 2008). The consequent inaccuracy and inconsistency in the use of definitions, according to Carvalho (1997), can bring a lower yield to studies, while knowledge is also reduced. In this case, when there is incompleteness in certain concepts, an alternative is to try to review and clarify them by combining new elements or the adaptation of existing ones, promoting epistemic reconstructions (Andion, 2012; Paula, 2016; Santos, 2017).

Given this context, the following question arises: How can a broader perspective of corruption contribute to the field of public administration? This essay aims to present reflections that broaden the understanding of the phenomenon of corruption beyond the functionalist and economic conceptions that dominate the studies of the Brazilian public administration. This study seeks a multidisciplinary interpretation that can rescue the concept of public interest and the political and moral aspect that is involved in corruption, thus providing the construction of knowledge that integrates instead of excluding.

As for the adopted methodology, considering its reflexive and interpretative nature, this study is structured as a theoretical essay. According to Meneghetti (2011a), studies of this kind are collectively built even if the limits are established by its author. It is an interaction between the 
subjectivity and objectivity of those involved, highlighting their dialectical character (Bertero, 2011; Meneghetti, 2011a). Thus, following the conception proposed by Meneghetti (2011a, 2011b) and Bertero (2011), in operational terms, although the preparation of this study followed an initial planning, its construction involved paths that were not predetermined.

Given this context, defining this work as a theoretical essay contributes to the study of corruption in Brazilian public administration in the sense of not limiting it to certain fields of analysis, i.e., involving purely economic and functional aspects. This avoids an approach to the phenomenon from polarized debates and epistemological lenses that do not yet dialogue with other fields of knowledge. Although the present paradigms in public administration help to understand the social phenomena, producing knowledge blindly based on a single worldview can lead to a restrictive scientific perspective, limiting the social reality and being little concerned about the quality and relevance of what is being produced (Barbosa, Santos, Matos, \& Almeida, 2013; Fadul, Silva, \& Silva, 2012; Paula, 2016; Santos, 2017).

This essay is structured in five sections, starting with this introduction. The second one presents questions related to the paradigms of public administration in Brazil. The third covers the different views of the literature on the phenomenon of corruption. In the fourth section, the limitations present in the perspectives that address corruption are analyzed, as well as the need to seek a concept that involves multidisciplinary perspectives and that reaches the public interest. The final considerations are presented on the fifth section.

\section{Paradigms in Brazilian public administration}

In the field of organization studies, the paradigm diagram proposed by Burrell and Morgan (1979) remains the subject of numerous debates by the academic community (Paula, 2016; Santos, 2017; Serva, 2016). The definition of paradigms was first used by Thomas Kuhn, according to whom science progress starts from scientific revolutions and behaves accordingly to a set of shared beliefs, values and techniques that, when accepted by the majority of the scientific community, become models of reference (Fernandes, D'Anjour, Añez, \& Silva, 2017; Kuhn, 1997). Starting from this study, to demarcate the organizational field, Burrell and Morgan (1979) presented to the academy four sociological paradigms - radical humanist, interpretive, radical structuralist and functionalist - in which the whole knowledge produced by the social sciences should fit (Caldas, 2005; Morgan, 2005).

The incommensurability thesis, in this context, is based on the impossibility of integration of different paradigms, since each has its own visions and definitions built from diverse perspectives (Burrell \& Morgan, 1979; Paula, 2016). Thus, researchers, when positioning themselves, should opt for a single paradigmatic lens, as it is impossible to conciliate more than one paradigm in a certain reality. In the perspective of Morin (1998), the adoption of a given paradigm besides controlling the reasoning to be followed by the researcher, it also influences the epistemological choice and, therefore, the theory and practice linked to it.

The construction of knowledge produced in the field of Brazilian public administration is also marked by the conception of paradigms that originate mainly from the governmental context of the time, administrative reforms and modernizations implemented by the State at certain political moments (Fadul et al., 2012; Keinert, 1994). Moreover, public administration studies in Brazil are 
still very recent and, since its formation, related to the presence of a conceptual body related to other areas (Fadul \& Silva, 2009; Pires, Silva, Fonseca, Vendramini, \& Coelho, 2014).

According to Andion (2012), public administration can be defined as an interdisciplinary field "that captures tensions between an instrumental rational orientation (aimed at expanding effectiveness and efficiency), on the one hand, and a political orientation (which considers the issues of values and aims to promote public interest), on the other" (p. 3, our translation). However, the nature of the relationship between administration and politics, at the conceptual and empirical level, is still a complex and widely discussed topic by scholars (Denhardt, 2012; Filippin, 2017; Goodnow, 2003; Weber, 1993; Wilson, 2005). Overall, the political and administration themes are analyzed from two different perspectives. The first advocates for the theoretical and practical distinction between politics and administration. On the other side is the idea of fusion or complementarity between these concepts.

In the conception of the interpretative perspective that addresses the administration-politics dichotomy, administration in the public sphere must be detached from politics, since merely administrative matters are not about political issues. Politics would thus be the environment of decisions relating to government matters, and the concern of the administration should be efficiency, with the improvement of working methods (Bresser-Pereira, 1998; Overeem, 2005; Wilson, 2005). On the other hand, the second approach argues that the purposes of the public administration are tightly bound to the interests of the government, so what exists between administration and politics is not a complete opposition, but an interdependence (Rouban, 2010; Svara, 1999; Waldo, 1948).

In Brazil, a dichotomous vision is still predominant and can be seen in the process of strengthening public administration as a discipline in Brazil (Andion, 2012; Coelho, 2008; Lourenço, Magalhães, \& Ferreira, 2014). In this perspective, the theoretical frameworks that marked the evolution and world views present in the field of Brazilian public administration can be nominated as: State-Centric, Pluralistic, New Public Management and New Public Service, and each is anchored in a predominant paradigm in a given period (Abreu, Helou, \& Fialho, 2013; Andion, 2012).

The first is characterized by the view of public administration as a legal science, which prevailed until 1929. In a second moment, between the 1930s until the 1980s, due to the interference of the authors of classical administration, with Taylor and Weber, this current focused mainly on the bureaucratic organization, the expansion of instrumental rationality and the distancing between politics and administration (Abreu et al., 2013; Keinert, 1994). At the end the 1980s, with the democratization of the country, public administration and political science became closer as academic disciplines. The pluralistic current, therefore, brought to the debate the importance of civil society as a political actor in the definition of political agendas and social control, enabling more critical studies in the field (Andion, 2012; Fadul \& Silva, 2009).

The New Public Management model emerged during the 1990s, from the adaptation and transfer of the management knowledge developed in the private sector to the public sector, through the combination of new forms of control and efficiency (Abrucio, Pedroti, \& Pó, 2010; Keinert, 1994). In 1995, as a result of the crisis, a broad reform program was implemented by the Brazilian government, which should reach the public administrative structure - emphasizing the adoption of management practices - via privatizations of companies (Abrucio, 2005; Bresser-Pereira, 1998). 
In response to the New Public Management, criticized for inadequate loan of values applied to the private sector, the New Public Service was developed in the mid-1990s. In such model, the idea of the public interest is constructed from a dialogue on common values, with the government having a role in which it acts to serve citizens rather than to control and direct them (Cançado, Tenorio, \& Pereira, 2011; Paula, 2005). This conception is based on the democratic political theory and the humanistic tradition of administration theory, as well as on the promotion and reaffirmation of the values of democracy, citizenship and public interest (Abreu et al., 2013; Denhardt, 2012).

From the perspectives introduced by the State-Centric, Pluralist, New Public Management and New Public Service currents, it is observed that the evolution of public administration studies in Brazil, in certain periods, is characterized by certain approaches that emphasize diverse theoretical fields and influence how knowledge is constructed (Fadul \& Silva, 2009). Table 1 presents the paradigmatic changes that the Brazilian Public Administration (PA) went through, its respective periods, the dominant paradigms and areas of knowledge that influenced the way in which these respective areas were seen.

Table 1

Paradigms of Brazilian public administration

\begin{tabular}{|c|c|c|c|}
\hline Periods & $\begin{array}{c}\text { Theoretical } \\
\text { Current }\end{array}$ & Dominant Paradigms & $\begin{array}{c}\text { Fields of knowledge that } \\
\text { influenced the PA }\end{array}$ \\
\hline 1900 to 1929 & \multirow{2}{*}{ State-Centric } & $\begin{array}{l}\text { Public Administration as Legal } \\
\text { Science }\end{array}$ & Law \\
\hline 1930 to 1980 & & $\begin{array}{l}\text { Public Administration as } \\
\text { Administrative Science }\end{array}$ & Administration \\
\hline 1980 to 1989 & Pluralist & $\begin{array}{l}\text { Public Administration as Political } \\
\text { Science }\end{array}$ & Political Science \\
\hline 1990 & $\begin{array}{c}\text { New Public } \\
\text { Management }\end{array}$ & $\begin{array}{c}\text { Public Administration as } \\
\text { Management Science }\end{array}$ & Economics \\
\hline 1995 & New Public Service & $\begin{array}{l}\text { Public Administration as co- } \\
\text { production of the public good }\end{array}$ & $\begin{array}{l}\text { Political Science and } \\
\text { Administration }\end{array}$ \\
\hline
\end{tabular}

Source: Elaborated by the authors based on Andion (2012), Fadul and Silva (2009), and Keinert (1994).

It is worth noting that the theoretical frameworks that guide studies in public administration in Brazil, notably the State-centric and the New Public Administration, are influenced by a functionalist and economic conception, which understand the public administration as a means of expanding the efficiency of the State completely far from the politics (Andion, 2012). Conversely, the Pluralistic perspective and the New Public Service bring new epistemological, theoretical and methodological assumptions for studies in public administration, which should be understood as a multidisciplinary field, to which many disciplines contribute, including economics, political science, administration (management), law and social science (Lourenço et al., 2014; Pires et al., 2014).

In this sense, Paula (2016) suggests a new development theory of knowledge in the social sciences that goes beyond the paradigms and diagram suggested by Burrell and Morgan (1979), since the promotion of epistemological debate through dichotomous positions ends up reducing 
and simplifying the construction of knowledge. The circle of epistemic matrices, elaborated by the author, consists of a theoretical construct with three epistemic matrices, each being related to a certain cognitive interest (Paula, 2016; Santos, 2017).

The empirical-analytical matrix is guided by technical interest and inspired by a positive philosophy and by formal logic, which produces knowledge to allow the control and prediction of social facts. Motivated by practical interest, the hermeneutic matrix seeks social understanding through interpretive logic and hermeneutics. On the other hand, the critical matrix, guided by an emancipatory interest, moves towards social transformation, based on a negative philosophy and dialectical logic. Together, these matrices represent different ways of explaining and capturing reality, based on distinct - although not exclusionary - cognitive interests (Paula, 2016).

Unlike the paradigm diagram, epistemic matrices circulate endless sociological approaches that are based on their theories and methods, for this reason there is no limit to the construction of knowledge systems (Paula, 2016). Thus, the incommensurability thesis of paradigms gives place to the idea of cognitive incompleteness, which refers to the impossibility of unique conceptions covering all knowledge, leading researchers to seek other theories that combine new elements or that recombine existing ones, thus performing epistemic reconstructions (Paula, 2016). To transcend cognitive limitations and provide more productive knowledge, the various approaches on a given theme can and should dialogue, seeking integration instead of exclusion (Santos, 2017).

In the field of public administration, research and even the teaching of disciplines still fail to reconcile, for the most part, the technical, practical and emancipatory interests that together represent the social reality. The field of public administration in Brazil is still very closed, conservative, formalist and permeated by disciplinary limits (Fadul et al., 2012). In that respect, it is still a challenge for public administration studies to understand the phenomena analyzed from a multi-, inter- or transdisciplinary view (Andion, 2012; Fadul \& Silva, 2009).

Thus, researchers still lack the notion that the phenomena addressed by the administration are somehow related to other fields of knowledge. Consequently, arises the need to integrate multiple theoretical bases and to open spaces for new ways to build and expand knowledge, through works that seek to reconcile the three types of cognitive interests or that, when choosing only one, are aware of their incompleteness.

\section{Historical aspects and definitions of corruption}

The Brazilian state apparatus has undergone a set of administrative reforms that improved institutional procedures and rules, management control mechanisms, tax accountability and transparency practices (Bresser-Pereira, 1998). However, while experiencing transformations in management, the governmental sphere still suffers from corruption, going through frequent political scandals that affect the legitimacy of the country and create a sense of distrust and impunity in Brazilian society (Filgueiras \& Aranha, 2011; Gomes \& Medeiros, 2019; Paiva, Garcia, \& Alcântara, 2017; Sodré, 2017).

This phenomenon, however, is not a result of contemporary times. The theme of corruption has been interpreted since antiquity from different conceptions related to political theory, which are inserted in certain spaces of experiences and horizons of expectations (Carvalho, 2008; Jain, 
2001; Mény, 1996). Historically the idea of corruption has been present since ancient Greece and related to the notion of destruction of political institutions (Filgueiras et al., 2010). From Aristotle's perspective, corruption was a political fact inherent to any form of government and that plays an important role in the cycles of rising and decaying of institutions, becoming a common practice in scenarios of crisis of Legitimacy (Cardoso, 2008). Thus, it would be up to the legal norms present in the constitutions to control potential corruption.

In the Roman world, corruption was also conceived as the nature of politics itself and was related to the lack of honesty and clarity in government decisions (Filgueiras, 2008). In this sense, the law would not be enough to address corruption, also being necessary to improve the civic virtues of the citizen. The medieval conception, due to the rise of Christianity, brought a new concept to corruption. In the face of the influences of Christian dogmas, politics was understood as sinful practice and corruption translated as luxury and greed, and only God, through the church, could redeem and save men (Filgueiras, 2008).

With the Renaissance, the concept of corruption underwent new transformations. Rather than essentially worrying about improving the governing apparatus as a way to control corruption, humanists prioritized the improvement of the public spirit and the morality of the citizen, as well as the values that guide political action (Bignotto, 2011; Filgueiras, 2008). Therefore, in the Renaissance point of view, corruption was linked to the lack of civic spirit within the political body and the apathy of the citizen in the face of matters of the republic, being inherent to all political orders, and its control was up to the civic virtues.

In contemporary political thought, there was again an amendment of the linguistic sense of the concept of corruption, untying it from the moral problem of virtues. Corruption came to be understood as the arbitrary use of power by the government, from which all forms of oppression and disorder result (Filgueiras et al., 2010). Thus, it would be up to the State, through a legal framework, to protect interests and functionally distinguish what is public and private interest, reproducing an order unbound from a moral virtue, focused on the systematization of needs in market societies (Filgueiras, 2008). Therefore, the control of corruption must be conducted in the presence of the market, which is responsible for moralizing interests and balancing power (Filgueiras, 2004).

In this context, from the 20th century, based on the different forms that corruption was historically addressed, the research agenda on the subject in Brazil is organized from three different aspects: the functionalist - which includes the patrimonialist approach - economic and legal positivit (Filgueiras, 2009; Filgueiras et al., 2010; Furtado, 2015; Martins, 2008).

The functionalist perspective, which dominated the research agenda since the 1960s, is related to the theory of modernization that emerged in the United States after World War II, having development as a research theme (Filgueiras, 2004). Starting from an understanding of social phenomena through ideal models, the main exponent of this current is Samuel Huntington (1975), according to whom corruption would be linked to the country's social, political and economic changes. Corruption is thus characterized as a functional and structural problem of a given society, according to its stage of political and economic development and its degree of institutionalization.

Still regarding the functionalist aspect, when corruption allows the breakdown of bureaucratic rigidity, the formation of private capital and the insertion of elites in the political arena, 
it can also contribute to the political and economic development of societies (Nye, 1967; Scott, 1969). However, in addition to its benefits, corruption, for functionalists, also has a cost if it is not controlled (Leff, 1964). The modernization theory, therefore, seeks to understand the costs and benefits of corruption for development, relating the malfunction of the political and economic system and, consequently, corruption, to the notion of underdevelopment. In this case, the way of fighting it would be the adoption of the views and practices of developed countries (Filgueiras, 2008; Merton, 1970).

In Brazil, this theoretical framework is related to the idea of patrimonialism, which associates the existence of corruption in the country with the culture and the very own identity and character of the Brazilian people (Faoro, 2000; Hollanda, 1995). For the literature that addresses this issue, corruption would be a customary practice, resulting from a historical organization of the State, characterized by a patrimonialism inherited from Portugal (Souza, 2008). Therefore, fighting corruption would take place through reforms that adopted the values of modern rationality, with the introduction of impersonality in the administrative apparatus and the separation between the public and the private spheres (Oliveira et al., 2016).

Since the 1980s, a new approach to corruption emerged, starting from Susan Rose-Ackerman in 1978, who had as theoretical basis the premises of rational choice and economic neoinstitutionalism. This conception became dominant in the 1990s, when New Public Management came to be defended by international financial institutions, assuming that corruption represents more costs for development than any benefits (Avritzer \& Filgueiras, 2011).

The literature on economic bias, thus, considers that the cause of corruption "is the existence of monopolies and privileges in the public sector, which create incentives for agents to seek to maximize their private income through bribery and kickback" (Filgueiras, 2004, p.142, our translation). The authors of this approach argue that the fight against corruption occurs through the transfer of political and economic activities commanded by the State to the market, aiming to break State monopolies and reduce the strength of bureaucracy and discretion (Lambsdorff, 2003; Mauro, 1997; Rose-Ackerman, 2002; Tanzi \& Davoodi, 1997).

In the context of the modern State, legal positivism also plays a prominent role, since it is the framework "responsible for rationalizing issues relating to law and justice, in addition to establishing, in the context of complex societies, forms of political legitimacy of the Nation State" (Filgueiras, 2004, p. 126, our translation). In this conception, corruption corresponds to the subordination of the public interest to the private interest, and the norm that rationally materializes the public interest and that, through coercion, prevents the search for individual benefits. This interpretative aspect, therefore, considers corrupt any act that fails to comply with the law, thus corruption is seen as the result of the lack of legitimization of the legal order and the ineffectiveness of the norms (Gardiner, 2002; Hodgkinson, 1997).

Table 2 summarizes how the theoretical functionalist, economic and legal positivist perspectives address the concept of corruption, its cause and how to combat it. 
Table 2

\section{Synthesis of the theoretical perspectives that address the corruption theme}

\begin{tabular}{|c|c|c|c|}
\hline $\begin{array}{l}\text { Theoretical } \\
\text { Framework }\end{array}$ & Concept of Corruption & $\begin{array}{l}\text { Cause of } \\
\text { Corruption }\end{array}$ & $\begin{array}{c}\text { Way of Combating } \\
\text { Corruption }\end{array}$ \\
\hline Functionalist & $\begin{array}{l}\text { Behavior of public agents who deviate from } \\
\text { acceptance of norms to serve private } \\
\text { interests, common in companies that do not } \\
\text { have a consolidated political and economic } \\
\text { institutionalization }\end{array}$ & $\begin{array}{l}\text { Low political and } \\
\text { economic } \\
\text { development }\end{array}$ & $\begin{array}{l}\text { Reforms to adopt rational } \\
\text { visions and practices of } \\
\text { developed countries }\end{array}$ \\
\hline Economic & $\begin{array}{l}\text { Use of public resources for the satisfaction } \\
\text { of private interests, provided by the } \\
\text { incentives created by the institutional } \\
\text { context that involves the actors }\end{array}$ & $\begin{array}{l}\text { Monopolies and } \\
\text { privileges in the } \\
\text { public sector }\end{array}$ & $\begin{array}{l}\text { Institutional reforms that } \\
\text { foster the market and } \\
\text { impose on democracy its } \\
\text { rules }\end{array}$ \\
\hline Legal Positivist & $\begin{array}{l}\text { Subordination of the public interest to the } \\
\text { private interest practiced by infringement of } \\
\text { the law emanating from the State }\end{array}$ & $\begin{array}{l}\text { De-legitimation of } \\
\text { the legal order and } \\
\text { ineffectiveness of } \\
\text { the rules }\end{array}$ & Legal rule \\
\hline
\end{tabular}

Source: Elaborated by the authors based on the studies literature.

From the analysis of such perspectives, it is observed that although they approach corruption through various lenses, all understand this phenomenon as the overlap of the private interest to the detriment of the public. What diverges between them are the causes that lead to corrupt practices and the ways to combat it. The legal positivist theory, due to its close relationship with law, studies corruption through a purely normative analysis. The functionalist aspect analyzes corruption according to the stage of modernization of society, attributing its occurrence to the lack of rationality found in developed countries. This economic view on the cause of corruption became even stronger when corruption began to be addressed from premises of rational choice and economic neoinstitutionalism, being understood as a consequence of the bureaucratic growth of the State.

Thus, for not adding to the meaning of corruption, political, moral, social and cultural aspects, the exposed theoretical frameworks cannot provide a conception of public interest that integrates the dimension of politics and morality. Some studies, however, already point out alternative perspectives to traditional approaches. Warren $(2004,2005)$ addresses corruption from discussions that resume democratic theory. According to the author, in addition to violating the norm of democratic inclusion, corruption also highlights the presence of a serious deficit of democracy. The organization or empowerment of civil society would thus be a way to promote accountability and contribute to politics without corruption (Warren, 2004, 2005). In Brazil, studies such as Avritzer and Filgueiras (2011), on combating corruption, also point out the need to strengthen non-state public control in an incisive way, allowing citizens to control and participate in collective decisions.

Parallel to the resumption of the democratic theory, some studies highlight electronic tools in the fight against corruption (Andersen, 2009; Bertot, Jaeger, \& Grimes, 2010; Lio, Liu, \& Ou, 2011). Such mechanisms - e.g., the Internet, social media and electronic government - facilitate control activities and would allow the prevention of corruption to the detriment of actions aimed at suppressing it. There are also research that argue that the combination of incentives for 
democratization and freedom of the press also contribute to the fight against corruption (Bhattacharyya \& Hodler, 2015; Camaj, 2013).

Studies addressing corruption from perspectives that go beyond traditional frameworks represent an opportunity to try to decipher such a complex and persistent phenomenon that provides numerous negative effects on public administration and society as a whole. Thus, a more critical scientific stance towards hegemonic aspects and overlapping conformations becomes necessary for a more complete understanding of corruption.

\section{Corruption and the public field: in search of an episteme that reaches the public interest}

The study of corruption is permeated by dichotomies, especially about the insertion of politics in the analyses. The market logic transported to the scope of public administration as a means of expanding the efficiency of the State caused corruption as a concept to be equally colonized by the economic and functionalist perspective, untying the phenomenon from issues related to politics and moral values. However, analyzing corruption from dichotomies such as development and underdevelopment or economy and politics leads to simplifications and reduces the understanding of a phenomenon that has accompanied societies since the beginning.

Table 2 shows that all the theoretical aspects analyzed have the private and public interests as the core that defines its concept, so the question of values as structuring elements of the political order can be disregarded for the analyses. The main focus of all these currents of thought, both with regard to the cause and the fight against corruption, is State and the Market related. The high bureaucratization rate of the State apparatus, its few effective norms or its institutions with low political and economic development are the central elements that determine the occurrence of corruption in the contemporary conception. Likewise, its fight would only be possible through the State, through its legal system or from management administrative reforms, being the market is responsible for stabilizing the selfish interests of the actors.

However, although all these approaches consider the issue of the public interest, it is observed that none of them analyze society's role in this scenario, as Warren $(2004,2005)$ and Avritzer and Filgueiras (2011) did. Given such dominant position of the literature, there is a reinforcement of what Habermas (2003) highlights as the transformation of the citizen into a client. According to Pinzani (2013), this aspect leads to the resignation of active participation by citizens, limiting them waiting for the provision of public policies of the State. There is a disruption, in this perspective, of every possibility of co-production of public services and policies since social apathy is perennial to the patronage model. This vision, according to Diefenbach (2009), expands the "Dark Side" of the strategy of the "New Public Management", since it contributes to the deepening of individualistic ideals and to a quantophrenia in public organizations, in which interest in results begins to overlap the democratic values that must guide public action.

However, the passive attitude of citizens is consistent with the interests of the market. The market enclave, like Ramos (1989) discusses in the work 'The new sciences of organizations', is powerful and leads the debate to an instrumental public reason. This strengthens the role of technocratic control and reduces societal control potential. In this context, the prominent discourse 
of expansion of transparency instruments and the deepening of the dimensions of accountability becomes contradictory, once the right to information, central throughout this whole process is intended for technocrats (Pinzani, 2013).

In a modern conception, based on economic rationality, law acts as an element that rationalizes the world of interests from a bureaucratic organization that separates the private from the public. The meaning of the word public interest, therefore, ceases to mean a space of political deliberation where the citizen has an active voice and is heard, turning into an utterance of the law or judiciary detached from the plane of values and political moral (Filgueiras, 2008). However, what this positivist perspective does not reveal is that behind each law that organizes the political order there are moral values that justify and motivate the existence of these norms, contributing to their creation and effectiveness.

However, studies based on a single approach hinder the recognition of new approaches, making the construction of knowledge on the theme ideology oriented, which leads to incompleteness of the produced knowledge. In this light, because they disregard cultural, social, moral and political factors in their analyses - integral variables for understanding the phenomenon - possible attempts to control and combat corruption can be equally limited. Therefore, a more plural approach that reconciles not only economic issues, but all these elements, can contribute to a more fruitful and comprehensive understanding of corruption, which is not restricted to merely market aspects.

Moreover, a plural approach can bring to the center of the public agenda a more complete understanding of corruption encompassing values and structuring elements of a democratic environment. Themes such as the theories of representation, public opinion, discursive formation and social practice, the formation of a democracy that develops from the base to the top; furthermore, the consideration of the global south becomes interesting in this new Approach.

The knowledge construction systems, as suggested by Paula (2016), must circulate through empirical-analytical epistemic matrices, hermeneutic and critic, allowing a reconciliation between technical, practical and emancipatory interests, necessary for understanding the social reality. Having a strong legal framework, which controls and predicts the occurrence of corruption (technical matrix), is useless if the meaning of this phenomenon is not completely understood from an interpretive logic (practical matrix) and if there are no reflections on the overcoming of this reality (critical matrix). Thus, only from the dialogue between these matrices corruption will be understood in a more complete and enlightening way.

To try to overcome the incompleteness existing in the studies on corruption, it is proposed that the epistemic reconstruction of the phenomenon in question starts from the conception of public interest as the result of deliberative and discursive processes among citizens. Thus, the focus of the debate is shifted from the State to society and from the market to the public sphere, understood as an environment of public deliberation detached from the structures of power (Filgueiras, 2008; Habermas, 2003; Lubenow, 2012; Mouffe, 2003). Thus, considering that the causes, consequences and solutions to corruption tend to be interconnected (Jain, 2001; Souza et al., 2019), the theoretical perspective called "Pluralist" is presented as an alternative proposal to the dominant currents of thought contained in Table 2. 
It should be noted that this approach is far from an accurate diagnosis of its causes and an exact definition of what effectively comes to be corruption. This vision seeks to build an interpretative perspective that integrates cultural, economic, civil and political elements into its analysis, thus allowing the meaning of corruption to be understood from a multidisciplinary matrix. Table 3 highlights this alternative perspective of understanding corruption, its causes and the ways to fight it.

Table 3

\section{Epistemic reconstruction of corruption}

\begin{tabular}{|c|c|c|c|}
\hline $\begin{array}{c}\text { Theoretical } \\
\text { perspective }\end{array}$ & Concept of corruption & Cause of corruption & $\begin{array}{c}\text { Way to fight } \\
\text { corruption }\end{array}$ \\
\hline Pluralist & $\begin{array}{c}\text { It is an action practiced by any individual } \\
\text { aiming to obtain personal gains to the } \\
\text { detriment of the public interest, which } \\
\text { contradicts cultural, moral and political norms } \\
\text { and values common and shared by society }\end{array}$ & $\begin{array}{c}\text { Individuals' inability to } \\
\text { control their personal } \\
\text { interests }\end{array}$ & $\begin{array}{c}\text { Law and Civic } \\
\text { Education }\end{array}$ \\
\hline
\end{tabular}

Source: Elaborated by the authors.

This understanding of corruption permeates the notion of public interest as something originated not only from the law but as the result of a process of deliberation performed by citizens, in which politics, the State and society are discussed (Avritzer \& Filgueiras, 2011). The public allows one to understand that corruption is not only linked to misuse of money. Thus, the simple change in the legal system available on corruption control or the reduction of incentive systems to corrupt practices are not enough if these institutional changes are not allied to social practices and accompanied by civic education (Filgueiras, 2008). In this context, the fight against corruption is not only related to the adaptation of the law and institutions to stricter systems, it also involves citizens' efforts.

The ways to fight corruption should therefore go beyond the establishment of rules. Laws will not take any effect if the values that support their existence and effectiveness do not follow the changes. Nor will it be of any use implementing bureaucratic mechanisms of combat if there is no relational perspective between the State and society; these two must walk together to control corruption. Thus, contrary to what the economic aspect preaches, based on a managerial model, the law is not the only way to control corruption, it is also necessary to active participation of citizens in the construction of public interest.

Thus, the causes of corruption also include the virtues of the individual and the difficulty in controlling their personal interests. This may explain the existence of corruption since antiquity, in different societies and in capitalist countries and with high development indexes, leaving evidence that the Market alone is not enough to inhibit the occurrence of the phenomenon. Corruption, in this sense, must be understood as something embedded in society, which requires greater reflexivity in relation to a multicultural construction of the term. Thus, its analysis is much more complex than it seems because it involves, in addition to economic factors, cultural, political and moral aspects. Recognizing the complexity of the term implies bringing back to its context 
relationships that were previously separated, comprising it from the multi-, inter- and transdisciplinarity (Andion, 2012; Fadul et al., 2012).

The pluralistic perspective, as well as Warren (2004, 2005) and Avritzer and Filgueiras (2011), highlights the need to insert civil society into the process of controlling corruption but also, combined with this, the importance of empowering institutions through a legal framework that can actually curb the practice of corruption. Moreover, the proposal of this study converges for the analysis of effective participation instruments that can amplify the aspect of the plurality of ideas, in other words, a constituent element of its epistemology is the construction of a democracy from the base to the top.

The public environment, in this sense, begins to provide fewer conditions for actors to engage in corrupt action, given that there is a network of institutions, normative, sociopolitical apt to fight corruption. These institutions emerge from the relations between State, Society and the Market. Values and the legitimacy of social action in the context of current democracies must be reshaped. As Mouffe (2003) points out, it means the strengthening a "vibrant people society where many conflicting views can express themselves and where there is a possibility of choice between legitimate alternative projects" (p. 1, our translation).

The technocratic environment, in this context, becomes 'one' of the strategic factors, such as social participation, from the point of view of the management of public policies, meaning it is not about empowering the role of technocrats beyond social participation. It refers to a discursive and social approach in which public actors involved (here public actors are understood more broadly) are equally able to expose their ideas. The construction of reason follows, then, a perspective beyond a purely instrumental activity and becomes of substantive connotations, meaning that democratic values, especially plurality, are valued and respected.

The pluralistic concept thus encompasses a critical core that seeks to broaden reflection on the democratic process itself. It is a question of responding to what Santos (2002) calls "democratizing democracy" under two ways: sociopolitical and epistemological. Sociopolitical because it involves the reincorporation of values and substantive rationality to debate. Epistemological, therefore, because reason is questioned and the search for autonomy of the public field becomes the compass of a collectively constructed knowledge.

Given the need for the redemocratization of democracy, reviewing the citizen's activist role in the process of regaining democratic trust is crucial (Pinzani, 2013). In fact, Robert Dahl (1997), coining the term polyarchy had the purpose of showing that the complexity present in the context of broader states can represent a gap in the entire democratic process. By considering Rousseau's contributions that democracies could be understood in small states, we see in current polyarchy an institutional capacity well below social demands.

In this regard, the plural concept of corruption tries to move forward by considering the role of political parties, of coalitions built for the construction of public policies, of social movements, which, in a broader angle, expands the challenging role of the citizen in front of the State. In this aspect that the analysis of corruption must be complex. It involves, in this sense, the search for social sovereignty that has as its principle the 'positive citizenship' that becomes fundamental in the elaboration of a collective project to combat corruption (Pinzani, 2013). 
The pluralistic approach thus corroborates with Urbinati (2006) by understanding that it is essential to resume public opinion as central in the discursive process and the formulation of policies to combat corruption. The role of representation is broad, and not only encompasses the legal and institutional aspect but also sociopolitical ones. The fight against corruption is thus understood beyond the role of the bureaucratic fiscal, making each citizen participate in the process of identifying corrupt acts and influencing the political direction of the country. Strengthening social participation from the formation of a citizen identity - seeking to modify the social identity of a country - becomes an element of this pluralistic view. In fact, this approach aims to contribute so the citizen can build their identity in an autonomous and active way. Contrary to what a Statecentered construction of a citizenship proposes, the pluralistic approach proposes an active citizen formation that promotes a civic culture and of interest in public affairs.

This proposal to rebuild the concept of corruption is not intended to extinguish discussions about it, as it is believed that a broader perspective of the phenomenon favors a more critical and in-depth debate on the subject. It is also known that all the knowledge produced is subject to cognitive limitations, for this reason, the interpretative perspective defended here does not represent a dogmatic position, just as it does not constitute the only possible truth. The greatest contribution of this study is to rescue some from the perspective developed by authors of ancient Greece, Romans and Renaissance, and therefore present reflections that broaden the understanding of corruption beyond functionalist and economic perspectives that dominate the studies of the Brazilian public administration, through a multidisciplinary interpretation that reaches the concept of public interest and the political and moral aspects involved in corruption.

Looking at the social sciences and, specifically, administration, from a single approach prevents advances in the search for other epistemologies that help deal with the complexity of the social phenomena that are studied. Also compromising the possibility of a critical analysis of the scientific knowledge produced, making it increasingly incomplete and distant from social needs and (Andion, 2012; Barbosa, Santos et al., 2013; Paula, 2016; Santos, 2017).

As a result, the scientific horizons must be broadened through works encompassing the three epistemic matrices (Paula, 2016). The incompleteness observed in the theoretical currents that address corruption is only one of the many that are present in the field and in public administration itself. Reflecting on how public administration has treated its objects of study from perspectives that are not only functional and economical allows new ways to understand the world, reality and other epistemological lenses.

\section{Final considerations}

This study sought to present a broader debate on corruption for the understanding of this concept from a plural reflection. Central aspects of democratic theory are resumed at its core, dialoguing with normative elements present in the process of formation of discourse and social practice. For the understanding of the concept of corruption both normative and institutional issues are considered, as well as political and social issues present in the debates of political representation and cultural elements found in the search for active participation in emerging democracies.

Regarding normative and institutional aspects, in fact, the pluralistic view of corruption does not fail to consider the search for legal milestones and the strengthening of instruments of 
accountability and transparency as essential for the fight against corruption. However, it also considers other aspects equally relevant in this process. Regarding the sociopolitical and cultural aspects, when considered in the scope of the discourse present in the public sphere, they can give the basis for questioning the rationality employed in combat instruments.

Given the theoretical approach analyzed, although corruption is a phenomenon that, in recent years, was shown to be persistent and present in the Brazilian public and private context, theoretical discussions about it still lack greater robustness, as is usually the case in the field of administration. Thus, one of the challenges for public administration studies, which includes corruption, is related to the difficulty of analyzing and understanding their respective objects of study not from a single vision. Scholars must accept that the phenomena addressed by the administration are somehow related to other fields of knowledge that are neither opposite nor excluding.

As a contribution to public administration, this study presents a reconstruction of the concept of corruption that integrates cultural, economic, moral and political elements into its analysis. This approach called "pluralist" allows the meaning of the phenomenon in question to be understood from a multidisciplinary matrix that goes beyond existing borders, dichotomous antagonisms and polarized debates. Its objective is to rescue the conception of public interest as the result of deliberative and discursive processes among citizens, expanding the analysis of corruption beyond the field of state and market, so society can be included. In addition, it contributes to the debate on the importance of civil society participation in the control of corruption, demonstrating that the key point for more effective control is not only reduced to the promotion of reforms in the law or the implementation of transparency mechanisms, but also the improvement of the civic virtues of the citizen.

With regard especially to the public field, this work advances in the discussion that studies based on a single aspect of scientific activity, being it the dominant view, collaborate little for the evolution of studies. In this context, another debate present in this study is the discussion about the way that knowledge in administration and corruption has been built by the scientific community. In the case of corruption, it was observed that an approach that contemplates the three epistemic matrices and that overcoming the dichotomies existing in the theoretical frameworks provides a more comprehensive understanding of this phenomenon.

It is worth noting, at last, what forms of incentives can be created by society or the State in order to promote a culture focused on civic education, to what extent civil society is effectively willing to contribute to the control of corruption and to what extent social participation in State affairs has been or may be effective. It also questions whether changing the selfish instincts of individuals is really possible and whether corruption would not be a phenomenon tied to human nature and thus impossible to be completely controlled in some ways. This may be an infinite debate, whose incompleteness will be difficult to overcome by scientific studies.

\section{References}

Abreu, A. C. D., Helou, A. R. H. A., \& Fialho, F. A. P. (2013). Possibilidades epistemológicas para a ampliação da Teoria da Administração Pública: uma análise a partir do conceito do Novo Serviço Público. Cadernos EBAPE.BR, 11(4), 608-620. doi:10.1590/S1679-39512013000400009 
Abrucio, L. F. (2005). Os avanços e os dilemas do modelo pós-burocrático: a reforma da administração pública à luz da experiência internacional recente. In L. C Bresser-Pereira \& P. K. Spink (Orgs.), Reforma do Estado e administração pública gerencial (6th ed., pp. 173-200). Rio de Janeiro, RJ: Editora FGV.

Abrucio, F. L., Pedroti, P., \& Pó, M. V. (2010). A formação da burocracia brasileira: a trajetória e o significado das reformas administrativas. In M. R. Loureiro, F. Abrucio, \& R. Pacheco (Orgs.), Burocracia e Política no Brasil: desafios para a ordem democrática no século XXI (pp. 27-71). Rio de Janeiro, RJ: Editora FGV.

Andersen, T. B. (2009). E-government as an anticorruption strategy. Information Economics and Policy, 21(3), 201-210. doi:10.1016/j.infoecopol.2008.11.003

Andion, C. (2012). Por uma nova interpretação das mudanças de paradigma na administração pública. Cadernos EBAPE.BR, 10(1), 1-19. doi:10.1590/S1679-39512012000100003

Avritzer, L., Bignotto, N., Guimarães, J., \& Starling, H. M. M. (Orgs.). (2008). Corrupção ensaios e críticas. Belo Horizonte, MG: Editora UFMG.

Avritzer, L., \& Filgueiras, F. (2011). Corrupção e controles democráticos no Brasil. Textos para Discussão CEPAL-IPEA, (32), 40p.

Barbosa, M. A. C., Neves, F. E. B., Santos, J. M. L., Cassundé, F. R. S. A., \& Cassundé, N. F., Jr. (2013). "Positivismos" versus "Interpretativismos": o que a Administração tem a ganhar com esta disputa? Revista Organizações em Contexto, 9(17), 1-29. doi:10.15603/19828756/roc.v9n17p1-29

Barbosa, M. A. C., Santos, J. M. L. D., Matos, F. R. N., \& Almeida, A. M. B. (2013). Nem só de debates epistemológicos vive o pesquisador em Administração: alguns apontamentos sobre disputas entre paradigmas e campo científico. Cadernos EBAPE.BR, 11(4), 636-651. doi:10.1590/S1679-39512013000400011

Bertero, C. O. (2011). Réplica 2: o que é um ensaio teórico? Réplica a Francis Kanashiro Meneghetti. Revista de Administração Contemporânea, 15(2), 338-342. doi:10.1590/S141565552011000200012

Bertot, J. C., Jaeger, P. T., \& Grimes, J. M. (2010). Using ICTs to create a culture of transparency: egovernment and social media as openness and anti-corruption tools for societies. Government Information Quarterly, 27(3), 264-271. doi:10.1016/j.giq.2010.03.001

Bhattacharyya, S., \& Hodler, R. (2015). Media freedom and democracy in the fight against corruption. European Journal of Political Economy, 39, 13-24. doi:10.1016/j.ejpoleco.2015.03.004

Biason, R. D. C. (2012). Temas de corrupção política. São Paulo, SP: Balão Editorial.

Bignotto, N. (2011). Corrupção e Opinião Pública. In L. Avritzer, \& F. Filgueiras. (Orgs.), Corrupção e Sistema Político no Brasil (pp. 15-42). Belo Horizonte, MG: Editora UFMG.

Brei, Z. A. (1996). Corrupção: dificuldades para definição e para um consenso. Revista de Administração Pública, 30(1), 64-77. Retrieved from http://bit.ly/3dPrSEI 
Bresser-Pereira, L. C. (1998). A reforma do estado dos anos 90: lógica e mecanismos de controle. Lua Nova, (45), 49-95. doi:10.1590/S0102-64451998000300004

Burrell, G., \& Morgan, G. (1979). Sociological paradigms and organisational analysis: Elements of the sociology of corporate life. London: Heinemann Educational Books. doi:10.4324/9781315242804

Caldas, M. (2005). Paradigmas em estudos organizacionais: uma introdução à série. Revista de Administração de Empresas, 45(1), 53-57. doi:10.1590/\$0034-75902005000100008

Camaj, L. (2013). The media's role in fighting corruption: media effects on governmental accountability. International Journal of Press/Politics, 18(1), 21-42. doi:10.1177/1940161212462741

Cançado, A. C., Tenorio, F. G., \& Pereira, J. R. (2011). Gestão social: reflexões teóricas e conceituais. Cadernos EBAPE.BR, 9(3), 681-703. doi:10.1590/S1679-39512011000300002

Cardoso, S. (2008). Platão e Aristóteles. In L. Avritzer, N. Bignotto, J. Guimarães, \& H. M. M. Starling (Orgs.), Corrupção ensaios e críticas (pp. 25-35). Belo Horizonte, MG: Editora UFMG.

Carvalho, J. M. (1997). Mandonismo, coronelismo, clientelismo: uma discussão conceitual. Dados, 40(2). doi:10.1590/S0011-52581997000200003

Carvalho, J. M. (2008). Passado, presente e futuro da corrupção brasileira. In L. Avritzer, N. Bignotto, J. Guimarães, \& H. M. M. Starling (Orgs.), Corrupção ensaios e críticas (pp. 237-242). Belo Horizonte, MG: Editora UFMG.

Coelho, F. S. (2008). A problemática atual do ensino de graduação em administração pública no Brasil. Cadernos EBAPE.BR, Edição Especial EnEPQ, 1-21. Retrieved from http://bit.ly/3kyGERC

Cordis, A. S., \& Milyo, J. (2016). Measuring Public Corruption in the United States: Evidence From Administrative Records of Federal Prosecutions. Public Integrity, 18(2), 127-148. doi:10.1080/10999922.2015.1111748

Dahl, R. (1997). Poliarquia: participação e oposição. São Paulo, SP: Edusp.

Denhardt, R. B. (2012). Teorias da Administração Pública. São Paulo, SP: Cengage Learning.

Diefenbach, T. (2009). New public management in public sector organizations: the dark sides of managerialistic enlightenment. Public Administration, 87(4), 892-909. doi:10.1111/j.14679299.2009.01766.x

Fadul, E. M. C., \& Silva, M. A. (2009). Limites e possibilidades disciplinares da administração pública e dos estudos organizacionais. Revista de Administração Contemporânea, 13(3), 351365. doi:10.1590/S1415-65552009000300002

Fadul, E. M. C., Silva, M. A., \& Silva, L. P. (2012). Ensaiando interpretações e estratégias para o campo da administração pública no Brasil. Revista de Administração Pública, 46(6), 1437 1458. doi:10.1590/S0034-76122012000600002

Faoro, R. (2000). Os donos do poder. formação do patronato político brasileiro. São Paulo, SP: Globo. 
Fernandes, L. T., D'Anjour, M. F., Añez, M. E. M., \& Silva, F. A. M. (2017). Paradigmas da estrutura organizacional: reflexões à luz de Thomas Kuhn. Paper presented at the 6th Colóquio Internacional de Epistemologia e Sociologia da Ciência da Administração, Florianópolis, SC.

Filgueiras, F. (2004). Notas críticas sobre o conceito de corrupção: um debate com juristas, sociólogos e economistas. Revista de Informação Legislativa, 41(164), 125-148. Retrieved from https://bit.ly/3kCXvTr

Filgueiras, F. (2008). Corrupção, democracia e legitimidade. Belo Horizonte, MG: Editora UFMG.

Filgueiras, F. (2009). A tolerância à corrupção no Brasil: uma antinomia entre normas morais e prática social. Revista Opinião Pública, 15(2), 386-421. doi:10.1590/S010462762009000200005

Filgueiras, F., \& Aranha, A. L. M. (2011). Controle da corrupção e burocracia da linha de frente: regras, discricionariedade e reformas no Brasil. Dados, 54(2), 349-387. doi:10.1590/S001152582011000200005

Filgueiras, F., Montandon, A., Oliveira, B., \& Abreu, I. (2010). Corrupção, cultura política e reformas no Brasil. Revista de Ciências Humanas, 10(2), 318-334. Retrieved from https://bit.ly/3aXV8qS

Filippin, M. (2017). Administração e política: uma relação dialética. Paper presented at the 6th Colóquio Internacional de Epistemologia e Sociologia da Ciência da Administração. Florianópolis, SC.

Furtado, L. R. (2015). As raízes da corrupção no Brasil: estudos de caso e lições para o futuro. Belo Horizonte, MG: Fórum.

Gardiner, J. A. (2002). Defining Corruption. In A. J. Heidenheimer \& M. Johnston (Eds.), Political corruption: concepts and contexts (3rd ed., pp. 25-40). Abingdon: Routledge.

Gomes, T. G., \& Medeiros, C. R. O. (2019). Construindo e desconstruindo escândalos de corrupção: a operação Lava-Jato nas interpretações da Veja e Carta Capital. Organizações \& Sociedade, 26(90), 457-485. doi:10.1590/1984-9260904

Goodnow, F. J. (2003). Politics and Administration: A Study in Government (3rd. ed.). New Brunswick: Transaction Publishers.

Habermas, J. (2003). Mudança estrutural da esfera pública: investigações quanto a uma categoria da sociedade burguesa (F. R. Kothe (Trad.). Rio de Janeiro, RJ: Tempo Brasileiro.

Heidenheimer, A. J., \& Johnston, M. (Eds.). (2002). Political corruption: concepts and contexts (3rd ed.). Abingdon: Routledge.

Hodgkinson, P. (1997). The sociology of corruption - some themes and issues. Sociology, 31(1), 1735. doi:10.1177/0038038597031001003

Hollanda, S. B. (1995). Raízes do Brasil. São Paulo, SP: Companhia das Letras.

Huntington, S. (1975). A ordem política nas sociedades em mudança. São Paulo, SP: Edusp.

Jain, A. K. (2001). Corruption: a review. Journal of Economics Surveys, 15(1), 71-121. doi:10.1111/1467-6419.00133 
Keinert, T. M. M. (1994). Os paradigmas da administração pública no Brasil (1900-1992). Revista de Administração Pública, 34(3), 41-48. doi:10.1590/S0034-75901994000300004

Klitgaard, R. (1994). A corrupção sob controle. São Paulo, SP: Zahar.

Kuhn, T. (1997). A estrutura das revoluções científicas (5th ed.). São Paulo, SP: Perspectiva.

Lambsdorff, J. (2003). How corruption affects persistent capital flows. Economics of Governance, 4(3), 229-243. doi:10.1007/s10101-002-0060-0

Leff, N. H. (1964). Economic development through bureaucratic corruption. American Behavioral Scientist, 8(3), 8-14. doi:10.1177/000276426400800303

Lio, M., Liu, M., \& Ou, Y. (2011). Can the internet reduce corruption? A cross-country study based on dynamic panel data models. Government Information Quarterly, 28(1), 47-53. doi:10.1016/j.giq.2010.01.005

Lourenço, C. D. S., Magalhães, T. F., \& Ferreira, P. A. (2014). Formação em Administração Pública no Brasil: desafios, perfil de formação e especificidades da área. Administração Pública e Gestão Social, 6(4), 177-186. doi:10.21118/apgs.v6i4.533

Lubenow, J. A. (2012). A categoria de esfera pública em Jürgen Habermas: para uma reconstrução da autocrítica. João Pessoa, PB: Manufatura.

Marani, S. C. Z., Brito, M. J., Souza, G. C., \& Brito, V. G. P. (2018). Os sentidos da pesquisa sobre corrupção. Revista de Administração Pública, 52(4), 712-730. doi:10.1590/0034-7612175197

Martins, J. A. (2008). Corrupção. São Paulo, SP: Globo.

Mauro, P. (1997). Why worry about corruption. Washington DC: International Monetary Fund.

Meneghetti, F. K. (2011a). O que é um ensaio teórico? Revista de Administração Contemporânea, 15(2), 320-332. doi:10.1590/S1415-65552011000200010

Meneghetti, F. K. (2011b). O que é um ensaio teórico? Tréplica à professora Kazue Saito Monteiro de Barros e ao professor Carlos Osmar Bertero. Revista de Administração Contemporânea, 15(2), 343-348. doi:10.1590/S1415-65552011000200013

Mény, Y. (1996). Fin de siècle corruption: change, crisis and shifting values. International Social Science Journal, 48(3), 309-320. doi:10.1111/1468-2451.00034

Merton, R. K. (1970). Sociologia: teoria e estrutura. São Paulo, SP: Mestre Jou.

Morgan, G. (2005). Paradigmas, metáforas e resolução de quebra-cabeças na Teoria das Organizações. Revista de Administração de Empresas, 45(1), 58-71. Retrieved from https://bit.ly/2ZSZqtf

Morin, E. (1998). O método. Porto Alegre, RS: Sulina.

Mouffe, C. (2003). Democracia, cidadania e a questão do pluralismo. Revista Política \& Sociedade, 2(3), 11-22. Retrieved from http://bit.ly/39bemYN

Nye, J. S. (1967). Corruption and Political Development: A Cost-Benefit Analysis. American Political Science Review, 61(2), 417-427. doi:10.2307/1953254 
Oliveira, T. M., Jr., Costa, F. J. L., \& Mendes, A. P. (2016). Perspectivas teóricas da corrupção no campo da administração pública brasileira: características, limites e alternativas. Revista do Serviço Público, 67, 111-137. doi:0000-0002-5524-3830

Overeem, P. (2005). The value of the dichotomy: Politics, administration, and the political neutrality of administrators. Administrative Theory and Praxis, 27, 311-329. doi:10.1080/10841806.2005.11029490

Paiva, A. L., Garcia, A. S., \& Alcântara, V. C. (2017). Disputas discursivas sobre corrupção no Brasil: uma análise discursivo-crítica no twitter. Revista de Administração Contemporânea, 21(5), 627-647. doi:10.1590/1982-7849rac2017160163

Paula, A. P. P. (2005). Por uma nova gestão pública. Rio de Janeiro, RJ: Editora FGV.

Paula, A. P. P. (2016). Para além dos paradigmas nos Estudos Organizacionais: o Círculo das Matrizes Epistêmica. Cadernos EBAPE.BR, 14(1), 24-46. doi:10.1590/1679-395131419

Pinho, J. A., \& Sacramento, A. R. (2018). O círculo vicioso da corrupção no Brasil: limites estruturais e perspectivas de rompimento. Revista do Serviço Público, 69, 181-208. doi:10.21874/rsp.v69i0.3262

Pinzani, A. (2013). Democracia versus tecnocracia: apatia e participação em sociedades complexas. Lua Nova, (89), 135-168. doi:10.1590/S0102-64452013000200006

Pires, V., Silva, S. M., Fonseca, S. A., Vendramini, P., \& Coelho, F. S. (2014). Dossiê - Campo de Públicas no Brasil: definição, movimento constitutivo e desafios atuais. Administração Pública e Gestão Social, 6(3), 110-126. doi:10.21118/apgs.v6i3.719

Ramos, A. G. (1989). A nova ciência das organizações: uma reconceituação da riqueza das nações (2nd ed.). Rio de Janeiro, RJ: Editora FGV.

Rose-Ackerman, S. (2002). A economia política da corrupção. In K. A. Elliott (Org.), A corrupção e a economia global (pp. 59-102). Brasília, DF: Editora UNB.

Rouban, L. (2010). A politização da administração pública. In B. G. Peters, \& J. Pierre. (Orgs.), Administração pública: coletânea (pp. 335-353). São Paulo, SP: Editora Unesp.

Santos, B. S. (2002). Democratizar a democracia: os caminhos da democracia participativa. Rio de Janeiro, RJ: Civilização Brasileira.

Santos, E. (2017). O campo científico da administração: uma análise a partir do círculo das matrizes teóricas. Cadernos EBAPE.BR, 15(2), 209-228. doi:10.1590/1679-395152841

Scott, J. (1969). Corruption, machine politics, and political change. The American Political Science Review, 63(4), 1142-1158. doi:10.2307/1955076

Serva, M. (2016). A Contribuição do Colóquio Internacional de Epistemologia e Sociologia da Ciência ao Campo da Administração no Brasil. Cadernos EBAPE.BR, 14(1), 1-11. doi:10.1590/1679-395158437

Sodré, R. J. M. (2017). Sobre corruptos, corrompidos e culpados: relatos de servidores públicos sobre práticas de corrupção. Revista de Contabilidade e Organizações, 11(31), 30-22. doi:10.11606/rco.v11i31.134465 
Souza, F., Midlej e Silva, S., \& Gomes, A. (2019). Corrupção no setor público: agenda de pesquisa e principais debates a partir da literatura internacional. Administração Pública e Gestão Social, 11(3), 1-18. doi:10.21118/apgs.v11i3.5640

Souza, J. (2008). Weber. In L. Avritzer, N. Bignotto, J. Guimarães, \& H. M. M. Starling. (Orgs.), Corrupção ensaios e críticas (pp. 81-90). Belo Horizonte, MG: Editora UFMG.

Svara, J. H. (1999). Complementarity of politics and administration as a legitimate alternative to the dichotomy model. Administration \& Society, 30(6), 676-705. doi:10.1177/00953999922019049

Tanzi, V., \& Davoodi, H. (1997). Corruption, public investment, and growth. In H. Shibata, \& T. Ihori (Eds.), The welfare state, public investment, and growth (pp. 41-60). New York: Springer.

Urbinati, N. (2006). O que torna a representação democrática? Lua Nova, (67), 191-228. doi:10.1590/S0102-64452006000200007

Waldo, D. (1948). The administrative state: a study of the political theory of American public administration. New York: Ronald Press.

Warren, M. E. (2004). What does corruption mean in democracy? American Journal of Political Science, 48(2), 328-343. doi:10.2307/1519886

Warren, M. E. (2005). La democracia contra la corrupción. Revista Mexicana de Ciencias Políticas y Sociales, (193), 109-141. doi:10.22201/fcpys.2448492xe.2005.193.42475

Weber, M. (1993). Parlamento e governo na Alemanha reordenada: crítica política do funcionalismo e da natureza dos partidos. Petrópolis, RJ: Vozes.

Wilson, W. (2005). O estudo da Administração. Revista do Serviço Público, 56(3): 349-366. doi:10.21874/rsp.v56i3.236

\section{Funding}

The authors would like to thank the financial support of Fundação de Amparo à Pesquisa do Estado de Minas Gerais (FAPEMIG) and Coordenação de Aperfeiçoamento de Pessoal de Nível Superior (CAPES).

\section{Authorship}

\section{Suélem Viana Macedo}

PhD student in administration in Universidade Federal de Viçosa (UFV).

Email: suelemvianamacedo@gmail.com

ORCID: https://orcid.org/0000-0002-1610-1856 


\section{Josiel Lopes Valadares}

PhD in administration by Universidade Federal de Lavras (UFLA). Professor of the Postgraduate Program in administration in UFV.

E-mail: adm_josiel@yahoo.com.br

ORCID: https://orcid.org/0000-0002-2559-9617

\section{Conflict of interests}

The authors have stated that there is no conflict of interest.

\section{Authors' contributions}

First author: conceptualization (equal), data curation (equal), formal analysis (equal), investigation (equal), methodology (equal), writing - original draft (equal), writing - review \& editing (equal).

Second author: conceptualization (equal), data curation (equal), formal analysis (equal), investigation (equal), methodology (equal), writing - original draft (equal), writing - review \& editing (equal).

\section{Plagiarism check}

O\&S submits all documents approved for publication to a plagiarism check, using specific tools.

\section{Data availability}

O\&S encourages data sharing. However, in compliance with ethical principles, it does not demand the disclosure of any means of identifying research participants, fully preserving their privacy. The practice of open data seeks to ensure the transparency of the research results, without requiring research participants to disclose their identity.

O\&S is signatory to DORA (The Declaration on Research Assessment) and to COPE (Committee on Publication Ethics).

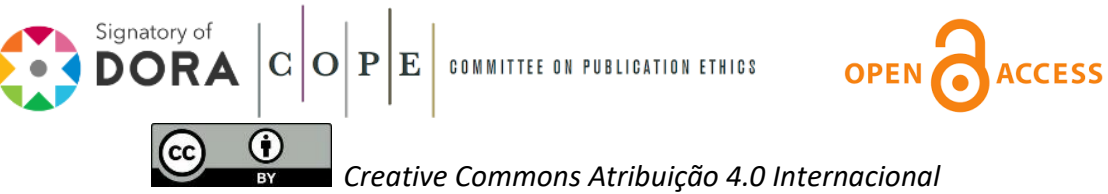

